\title{
Asian Anticipations of Cosmopolis
}

Participation and Distribution Decisions in Japan's Industrial Relations Systems after World War II - Evidence of Conversation and Workplace Evangelization

Tackney, Charles T.

Document Version

Final published version

Publication date:

2009

License

CC BY-NC-ND

Citation for published version (APA):

Tackney, C. T. (2009). Asian Anticipations of Cosmopolis: Participation and Distribution Decisions in Japan's Industrial Relations Systems after World War II - Evidence of Conversation and Workplace Evangelization.

Department of Intercultural Communication and Management, Copenhagen Business School.

Link to publication in CBS Research Portal

\section{General rights}

Copyright and moral rights for the publications made accessible in the public portal are retained by the authors and/or other copyright owners and it is a condition of accessing publications that users recognise and abide by the legal requirements associated with these rights.

Take down policy

If you believe that this document breaches copyright please contact us (research.lib@cbs.dk) providing details, and we will remove access to the work immediately and investigate your claim.

Download date: 26. Apr. 2023 


\section{WORKING PAPER}

2009, nr. 2

Thursday, August 27, 2009

\section{Asian Anticipations of Cosmopolis: Participation and Distribution Decisions in Japan's Industrial Relations System after World War II - Evidence of Conversion and Workplace Evangelization}

by Charles T. Tackney

Ph.D., Associate Professor

Department of Intercultural Communication and Management

Porcelænshaven 18 A, DK-2000 Frederiksberg

Copenhagen Business School 
Previously presented June 26, 2009 at the Thirty-sixth Annual Lonergan Workshop at Boston College. Comments are welcome. Do not cite without author permission.

\section{Contact information:}

Charles T. Tackney

Department of Intercultural Communication and Management

Copenhagen Business School

Porcelænshaven 18A

Frederiksberg, Denmark 2000

+45-3815-3188 (Office tel.)

+45-2465-4801 (Mobile)

ct.ikl@cbs.dk (email) 


\section{Table of Contents}

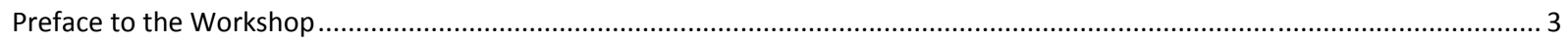

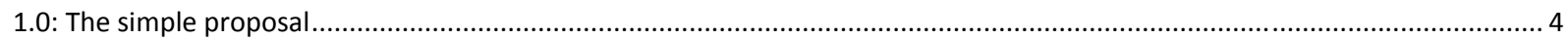

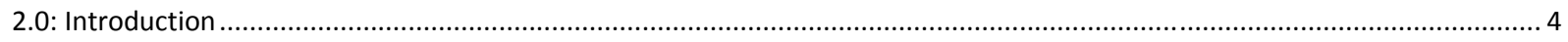

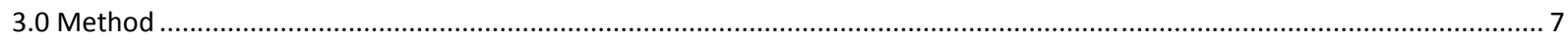

4.0: The Post-war Japanese Industrial Relations Settlement: Workplace Evangelization by Administrative Recommendation and

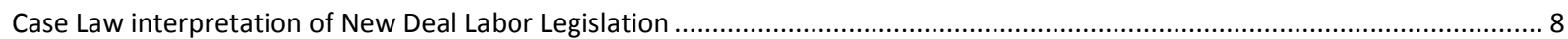

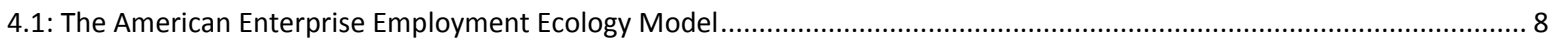

4.2: The German Enterprise Employment Ecology Model: Just Cause, Legislated Co-determination, and Works Councils........ 9

4.3: The Japanese Enterprise Employment Ecology Model: Just Cause, Management Councils, and Case Law Norms............ 12

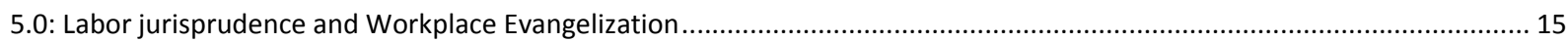

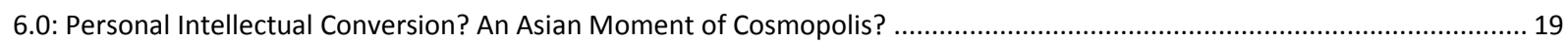

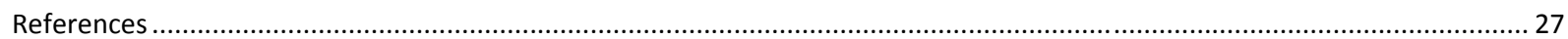

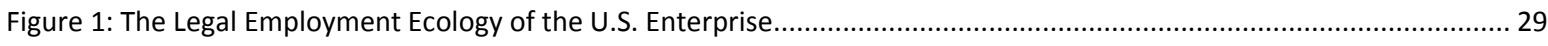

Figure 2: The Legal Employment Ecology of the German Enterprise ......................................................................... 30

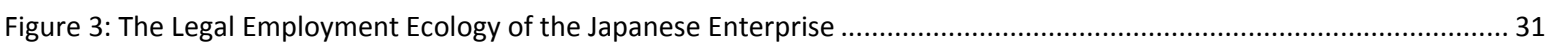

Appendix 1: Central Labor Relations Commission Guidelines for Management Participation Forums ...................................... 32 


\section{Preface to the Workshop}

In this paper, and even more in presentation, I will be going out rather far out on the limb of my training in industrial relations. Such is, perhaps, the intent of the collaborative process envisioned by Lonergan, no less than the theme of this conference. It will be evident from my referencing specializations far from my field, along with the shaky tone of voice, that the limb is beginning to bend and, perhaps, may be about to give way. If the participants could offer a turning word that will aid this investigation, I would be grateful.

This paper takes the form of an extended essay. We begin with a very simple and specific policy proposal for the current U.S. economic crisis, which I offer from my studies in industrial relations. Thereafter, as the section headings suggest, we will venture far afield. The distance travelled is necessary due to the topic, the nations, and the cultures involved. My aim is, first, to shed light upon one particular set of decisions taken in Japan, in the immediate aftermath of the Pacific War, and how these effected industrial relations developments thereafter. Second, and on a different level of analysis, I will present evidence that singular collaboration took place in Japanese history, at a specific point in time, that certainly appears to anticipate the notion of cosmopolis as Lonergan describes this utopian scheme. Third, I will end with brief points of possible further interest to Lonergan scholars. 


\section{0: The simple proposal}

In light of the current economic crisis we are all well aware of, and based on the evidence and effects reported below, the U.S. Central Labor Relation Commission should immediately permit experimentation in the collective-bargaining based use of employee participation arrangements throughout the country.

Employee participation arrangements are well known throughout the industrialized world; these remain functionally illegal and largely unknown in the United States of America. As we will see, ‘employee participation’ does not simply mean incentive compensation, production line halt authority for quality assurance, or stock options. It is a very important concept in industrial relations and one that appears to reside outside U.S. economic ideological parameters.

I begin with this simple proposal because it comes from a decision to do precisely this in Japan, in the immediate aftermath of the Pacific War and with the same legislative basis. That decision forms the main thesis of this paper, which can be stated here: Japan's post-war 'web of rules' governing employment relations represents a remarkable form of workplace evangelization that may offer an anticipatory benchmark in the collaboration expected of cosmopolis in the works of Bernard J.F. Lonergan.

\section{0: Introduction}

Among other things, Lonergan was an economist. He was interested in economic cycles and circulation effects, as anyone who has inspected and struggled over his diagrams on the subject know. In this paper, I am particularly interested in the decisions and the decision-makers who impact these circulation effects in one area of economics and legal policy: the role and function of managerial 
prerogative and its relation to employee participation in enterprise governance. For those familiar with German industrial relations, we are talking about works councils and their various manifestations throughout the world - with the notable sole exception, among the leading industrialized nations, of the United States. Even the United Kingdom now hosts EU Works Councils, according to legal obligation.

To date in my studies, I have found Lonergan rather quiet on these specific issues in the economics texts I have read. Perhaps his era required the higher order macro-economic analysis. Certainly his macro-economic analysis enables us to think about the lesser order topic of today more clearly: what is management? I suppose 'lesser order' is a poor word choice, because, in fact, it has been the serial and systemic lack of insight into the management function that has, ironically, caused a dreadful failure of circulation effects throughout the world of late. The interdependent scale of this failure is such that even Lonergan, perhaps, could not have imagined the linkage between a relatively constrained lack of insight into managerial prerogative and its vast global consequences.

However, he certainly imagined something big, interdependent, collaborative, and residing in the future. There would come a time when those able to make intelligent and reasonable decisions will function properly on behalf of the commonweal: cosmopolis (1992). It has always been curious to me that an individual so painstakingly detailed in epistemology and economic analysis would deliberately point us all forward to a time when leaders competent to lead actually would lead - and properly do so. Yet, as you know, in Insight this pointing is by way of negation regarding the cast of this cosmopolis reality drama; it recalls the Hindu approach to finding God through specification of what God is not.

A key to collaboration, which cosmopolis presumes, is trust. Trust is a matter of interest in crosscultural studies involving comparative economic performance (Fukuyama, 1995). In the critical management studies literature, Adler (2001) identified trust as "the key coordinating mechanism in the community form” (p. 176). And, working backwards through Adler's text presentation, the community is the constituting outcome of informal organization. He noted three sources of trust: familiarity, interests (and their calculation), and values/norms. Trust is generated via any of three mechanisms: direct 
interpersonal contact, reputation, or "by our understanding of the way institutions shape the other actor's values and behavior” (pp. 176-177).

A vast literature identified Japanese culture, management, and modes of production as being profoundly based on trust. Fukuyama views it at a key explanatory variable for Japanese success in the comparative political sphere (1995). Aoki $(1987,1988)$, Koike $(1987,1988)$, and Ouchi see trust to be of critical importance for Japanese management practices. Others see the concept as central for Japanese modes of production, whether domestically - in Japan (Morgan, J.M., \& Liker, J.K., 2006) or in the successful export of these practices abroad (Liker, J.K., Fruin, W.M., \& Adler, P.S., 1999):

What I plan to specify in this paper is how Japanese legal scholars freely adapted foreign, decidedly Western, and specifically Continential European legal constructs to advance this 'Asian culture'of trust as a workplace value. And this story is even more intriguing because trust, which the literature clearly attributes to the Japan case (and not, in contrast, to the U.S. - or, at a minimum, not in remotely the same way), emerged from post-war Japanese circumstances, which feature essentially identical U.S./Japanese labor legislation.

Still, we must go one step further. We will bring this industrial relations research into Japan’s post-war lifetime employment system to Lonergan's legacy of cosmopolis. This is because of the political and legal decisions made in and around 1946 and the legal grounding that informed these decisions. Japanese policy makers turned to Continental European jurisprudence to craft rules of employment appropriate to their Asian condition. Curiously, Western law was deployed to reinforce and reinvent Japanese culture. There is yet more - these steps, which we will explore below, constituted an explicit Christian evangelization of the Japanese workplace: a self-evangelization, if you will. The key players may or may not have been Christians in any formal sense. The father of Japanese labor law, Professor Izutaro Suehiro, was not - to my knowledge - a Christian. Yet, he explicitly noted the profound gratitude Japanese labor law scholars should feel for the Judeo-Christian tradition that had played such a role in 
Japanese legal studies and development. In this, Continental European labor jurisprudence was the distinction that has made all the difference.

In subsequent decades, as the Japanese "Economic Miracle” began to be felt abroad in increasingly value-added, excellent quality products, the effects of these decisions were perceived to be and actually were - threats to the American workplace (Kochan, T.A., Katz, H.C., and McKersie, R.B., 1986). As we shall see, the Japanese insights in a particular 1946 moment of cosmopolis may be precisely what is called for now to rescue the American set of 'working rules' that govern employment relations. If this is a proper judgment, we should ask if the American cosmopolis, in anticipation or fact, is actually up to the task of enactment? And who will these individuals be to ensure good decisions are made in a timely manner?

\subsection{Method}

This is an extended essay primarily concerned with the field of industrial relations. Industrial relations is an academic discipline that studies the "web of rules" or "working rules”[2] that govern employment relations at the workplace, firm, region, industry or nation (Dunlop, 1958, 1993).

To appreciate the significance of the post-war steps taken by Suehiro and others, we begin with a brief resume of industrial relations theory from the perspective of the settlement achieved by 1946. Three analytical models of enterprise employee ecology will be presented and explained. The second step will be to summarily note the nature of the workplace evangelization that obtained and has since carried forth into what is now termed "Japanese management practice," and its consistency with Roman Catholic social teaching. Third, we turn to the issue of cosmopolis, with brief notes about some possible implications for Lonergan studies. Some are given in this working draft. Others will be presented at the conference if possible. 


\section{0: The Post-war Japanese Industrial Relations Settlement: Workplace}

\section{Evangelization by Administrative Recommendation and Case Law}

\section{interpretation of New Deal Labor Legislation ${ }^{1}$}

Three measures differentiate the Japanese employment ecology of the enterprise from that of the U.S. First, just cause is the only grounds for dismissal - and fiscal difficulties are presumed by the courts to be the responsibility of management, so economic redundancy dismissals are extremely problematic to enact. Second, Japan localizes works councils in the collective bargaining agreement. Third, case law provides an ongoing method to modify practice as history proceeds.

One man, Professor Izutaro Suehiro, was instrumental in all three measures. To grasp the significance of this accomplishment, we must begin with the U.S. employment ecology model. After all, that was the same legislative basis Suehiro had to work with in 1946.

\section{1: The American Enterprise Employment Ecology Model}

While the topic is Japan, we begin with the U.S. model because it is easiest to understand and the Japanese later did such entertaining and interesting things to it. Since the New Deal labor legislation and significantly - the legal interpretations of the National Labor Relations Commission, American workers may unionize. Unions negotiate over wages and working conditions. The nature of the U.S. employment contract is “at will”; employer and employee are presumed equal parties to the contract. Functionally, 'at will' employment permits the U.S. employer to dismiss for a good reason, a bad reason, or no reason.

\footnotetext{
${ }^{1}$ This section adapted from Tackney, Charles T. (August 2009). Sustainability in employment ecology models of the modern firm:a critical management studies comparative assessment based on Japanese industrial relations research. To be presented at the Critical Management Studies Division of the 2009 Academy of Management conference, Chicago.
} 
There are, of course, federal restrictions against discriminatory employment practices (religion, race, party affiliation, gender, and, most recently, age). State legislation may further restrict 'at will' dismissal prerogative. Collective bargaining agreements further constrain managerial range of action.

The legal employment ecology of the U.S. enterprise is given in Figure 1. Solid black lines between management and employees depict the fundamental adversarial nature of their relationship. Apart from wages and working conditions - dealt with through unions - there are no formal, institutionalized mechanisms to negotiate or discuss matters relating to authority, power, fiscal transparency, detailed management decisions, strategies or plans. Insofar as employees are granted additional rights or discretionary power - stock options or other forms of 'employee empowerment' these are strictly at the discretion of the employer. That is shown by the downward arrow to the right.

Figure 1 here.

This schematic does not intend to negate the prevalence or role of work teams in the U.S. As we shall see, these simply, and factually, lack the institutional stature recognized in other national settings. They do not, for example, have a role for voice in the organization as concerns executive compensation or inordinate risk-taking by one department, which may lead to the failure of the firm.

\section{2: The German Enterprise Employment Ecology Model: Just Cause, Legislated Co-determination, and Works Councils}

While the German model parallels that of the U.S. concerning collective bargaining, stark differences are immediately visible when shown in a simple diagram. It is illegal to dismiss for a bad reason or no reason in Germany and the EU. The German model (and, I note, the European Union works 
council model since 1994) obliges, by legislation, works councils in firms beyond a certain size. Works councils can be defined as, "institutionalized bodies for representative communication between a singe employer (management) and the employees (workforce) of a single plant or enterprise” (Rogers, J., and W. Streeck, 1995). In addition, at the top level of an enterprise governing board, proportional representation by elected representative of employees is also obligatory by legislation. Taken together, works council and board membership participation in the function of a German enterprise are referred to as “Co-Determination” (die Mitbestimmung). The German Co-determination schematic of Figure 2 depicts a degree of transparency and participation in authority, information, and resource control by the dotted lines that separate management and works councils. This is in contrast to the solid lines separating union and management functions.

Figure 2 here.

Co-determination in Germany has a history that has been traced to the 1848 Frankfurt National Assembly (Jackson, G., 2001). As we shall soon see, the Japanese postwar legal employment ecology is profoundly influenced by the German case. This is the reason for taking it up after the U.S., but before the Japanese model.

Before we look in more detail at the works council features of co-determination, recent developments oblige note that the European Union has adopted participation as an integral polcy. In 2005, the European Trade Union Confederation (ETUC) reported the following on its website:

The claim that co-determination is an alien concept in Europe does not stand up to scrutiny...Even though the German arrangements regarding worker participation are more extensive than in other European countries, Hoffmann points out that this is far from equivalent to saying that other European countries have widespread co-determination free areas. In fact, 18 of the 25 EU Member States have binding rules governing co-determination, and in many cases their 
arrangements provide for an extensive workforce presence on companies' supervisory boards. In the new Member States company bodies are taking their lead from German law, and in Slovenia by law- companies employing more than 1,000 staff have to guarantee the workforce $50 \%$ participation (EUC 8 A.D.). ${ }^{2}$

This development both recalls, and strengthens, a 1995 observation by Wolfgang Streeck. He wrote of the "largely forgotten" process of "the almost universal establishment of works councils after 1945 in otherwise very different national contexts, as an integral part of a worldwide recasting of the political economy of capitalism” (Streeck, W. 1995, p. 313).

It will be useful to elaborate on the possible range and role of works councils, precisely because of their varied manifestations in different national settings. Works councils, briefly:

- Represent all the workers at a given workplace, irrespective of their status as union members.

- Represent the workforce of a specific plant or enterprise, not an industrial sector or a territorial area.

- Are not ‘company unions'.

- Differ from management policies encouraging individual workers to express their views and idea, as well as new forms of work organization introduced to increase the "involvement" of workers.

- (Enable) representative communication between employers and their workforces, (which) may be of all possible kinds and may originate from either side.

- May (the usual case) or may not have legal status.

- Structures vary widely across and within countries.

- Are not the same as worker representation on company boards of directors. (Rogers and Streeck, pp. 6-9).

\footnotetext{
${ }^{2}$ Hoffmann is Deputy General Secretary Reiner Hoffmann, speaking at an IG Metall conference on worker participation held in Dortmund on 17 November 2004.
} 
Rogers and Streeck specified three 'ideal types’ of works councils. First, paternalistic councils are those formed by employers or government. They permit worker representation only to the extent that the independent expression of worker interest is constrained, by prior intent. In this respect, there is a political dimension to their establishment. Second, consultative councils are primarily for economic purposes. Consultative councils seek to enhance communication with the goal of enhanced firm competitiveness and, possibly, the implementation of reward or incentive systems. These councils supplement the firm's functional organization. And third, representative councils "are typically established through collective agreements or legislation giving the entire workforce of a plant or enterprise (again, unionized or not) some form of institutionalized voice in relation to management” (p. 10). In contrast to consultative councils, representative councils are "part of a firm’s political system” (p. 11).

Given this background on the U.S. enterprise legal employment ecology and informed of the German variant, which includes just cause dismissal protections, works councils, and board representation, we are ready to turn our attention to the Japan case. It was in Japan, shortly after the end of World War II, that works councils were adapted from their German origins to creatively resolve a political crisis within a devastated Asian nation.

\section{3: The Japanese Enterprise Employment Ecology Model: Just Cause, Management Councils, and Case Law Norms}

The initial design notion for the comparative legal employment ecologies of U.S., German, and Japanese firms was due to the study of the institutionalized practice of lifetime employment in Japan (Tackney, C.T., 1995). Izutaro Suehiro, a civil and labor law specialist, was instrumental in the establishment of three postwar industrial relations practices. The first was study and systemization of the role of case law as a pattern and norm generating legal resource - beginning long before World War II. The second was post-World War II ‘just cause’ case law restrictions on managerial dismissal prerogative - initially appearing, quite ironically, in dismissal efforts by Occupation forces against redundant 
Japanese employees. The third was the localization of employee participation prerogative (modeled on German works councils) within the postwar Japanese collective bargaining agreement.

Suehiro's various contributions to Japanese legal studies are recognized by a small number of legal scholars in Japan. While his name is widely known among Japanese, his specific contributions are far less well recognized. In the field of law, his approach is known as “Suehiro jurisprudence” (末弘法学). This is a fairly well known phrase in Japanese, but the precise content of the term remains rather amorphous. Most Japanese will find it difficult to signify what this approach precisely means. For present purposes, it is only necessary to keep in mind that Suehiro's contributions to Japanese labor law jurisprudence, reviewed above, stand upon distinct, and distinctively Continental European interpretation of employment and contract. These interpretations were made in reference to legislation essentially identical to that which the U.S. refers to as New Deal legislation.

Following legal interpretations extant in continental Europe, Suehiro jurisprudence presumes that the labor contract is inherently unequal; the hired worker is comparatively disadvantaged in comparison to the hiring employer. Accordingly, corrective measures should be taken by the government and courts, with appropriate norms becoming 'codifed' through case law outcomes. As a means to overcome extremely antagonistic confrontations between Japanese employers and unionized workers in the aftermath of World War II, Suehiro was instrumental in the crafting of a July 1946 Central Labor Relations Commission (CLRC) guideline document that advocated creation of "Management Councils" ( 経営協議会, keiei kyogikai). These were modeled on German works councils, but uniquely based in firm-specific collective bargaining agreements.

Due to case law restrictions enforcing just cause as a restriction against managerial dismissal prerogative and the single CLRC document issued in July 1946, the Japanese firms's legal employment ecology is radically different from that of its U.S. counterpart. The difference in degree of the legal 
interpretations given in respect to similar legislation - by the Japanese courts and the CLRC - resulted in

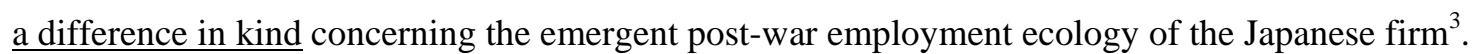

The Japanese model is given in Figure 3. As Japan's management councils arise from the collective bargaining agreement, there is an obvious transparency of form and function between the labor union and the management council. This is depicted by the dotted line between them. In turn, the relationship between the management council and management is also variable and varied. This is also depicted by a dotted line.

Figure 3 here.

Suehiro and those with whom he worked localized management councils in the collective bargaining agreement because they felt the German approach did not get the nature of the function quite correct. Proximity to the actual market itself seemed best, for flexibility, adaptability, and the sustainability of the enterprise. In addition, the Japanese approach places no theoretical limit on the degree to which employee voice may assert itself in the life of the enterprise.

Apparently, this approach remains a useful and ubiquitous feature of Japanese firms. While German and EU law specify a minimum number of employees in a firm before works councils are mandated, Japan has no such restriction. Data from a 1999 survey indicate that $41 \%$ of all Japanese firms have some form of management council; 58\% do not. Yet, $85 \%$ of unionized firms have them. Furthermore, 78\% of firms having 5,000 or more employees report the presence of such councils (Ministry of Labor Policy Secretariat Survey Section, 1999). Data from a subsequent survey show the rate

\footnotetext{
${ }^{3}$ For a thorough examination of Suehiro's adaptive appropriation of Weimar era German jurisprudence, see Kettler, D., and Tackney, C.T. 1997.
} 
of participation for firms with 5,000 or more employees increased to $81 \%$, while there was a decline in the overall national rate to 37\% (MHLW, 2004).

These practices are the legal foundations for the later emergence of "lifetime employment” as an institutionalized practice which was, itself, first recognized in Japanese case law only in 1961 (LexDB 27611297, 1961, Hanrei Jiho). The institutionalized practice was most recently reaffirmed in 1997 by the Japanese Supreme Court as "what has come to be taken as ‘the premise of our nation's labor conditions’” (LexDB 28020596, 1997).

Thus, from all available evidence, it appears that it is primarily from these two principles - just cause and employee participation - that led to the cultural affirmation of lifetime employment through the Supreme Court decision. These are the distinctive and defining features of post-World War II Japanese industrial relations. Furthermore, by keeping these principles in mind it becomes possible to trace, extract, export, appropriate and objectively evaluate "Japanese management theory and practice” in all its research, application, and consulting manifestations.

\section{0: Labor jurisprudence and Workplace Evangelization ${ }^{4}$}

Thus far, we have seen that “Japanese management” and Japan’s “lifetime employment system” are both actual, traceable outcomes of postwar working rules of industrial relations. These rules, evident in the creation of judicial and quasi-judicial institutional norms, arose from

\footnotetext{
${ }^{4}$ This section adapted from Tackney, C.T. (April 2009). "Ye shall know them by their fruits": American Workplace Evangelization and the Continental European Jurisprudence Origins of Japanese Management Practice. Journal of Management History, 15:2, 178-197.

http://www.emeraldinsight.com/Insight/viewContentItem.do;jsessionid=B558C821E330E73AAF40A34F59F0B275?contentType=Article\&conte ntId=1782701
} 
adaptive appropriations - to an Asian context - of continental European, primarily German, labor law principles of jurisprudence (Tackney, 1995). These adaptations, when appropriately deployed, are, in fact, much closer to Roman Catholic social teachings on the nature of the firm in modern society than the working rules of employment commonly found in the US industrial relations system. Thus, the export to or appropriation of "Japanese management practice" to the USA (or other national systems) can be properly, if unexpectedly, understood as a surprising evangelization of American management practice no less than a continental European reevangelization of the American workplace. Of course, this will be so only if good practice obtains; there is a double-edged sword facet of Japanese management implementation.

It may, in fact, reflect a more "integrated" civil society mode that parallels legal constructions more familiar to the European Union - at least when certain criteria are met. What this specification of "working rules" accomplishes is to clarify the chronological "puzzle" of initial US research enthusiasm yielding to later critical re-appraisals of “Japanese management practices” as they were deployed in the US industrial relations system. In other national settings, similar patterns of enthusiastic reception changing to later cautionary positions may be found in other national settings that lack the conditioning parameters of just cause and employee participation.

We have seen that the legal inspiration for "just cause" and management council adaptive appropriation in postwar Japanese industrial relations were derived from Germany and German jurisprudence. There is no question that the Japanese legal scholars of the postwar era were well versed in German legal studies and labor law. No one exemplified this level of scholarship more than Suehiro Izutaro. 
However, another aspect of the European appropriation to postwar Japan lies in the Christian and Roman Catholic tradition of teachings on civil society. These were, at a primary level, known to the Weimar political parties and their policy makers. ${ }^{5}$ Further, the Japanese legal scholars of the period, including Suehiro, were well aware of Roman Catholic social teaching. Kaufman (2004, p. 76), describing the global evolution of industrial relations, wrote, "in Japan many of the earliest Japanese labour scholars and union activists had earlier converted to the Christian faith.” It will be of interest, then, to briefly review the key document of the period which informed their knowledge: the Encyclical Rerum Novarum (On Capital and Labor) of 1891 by Pope Leo XIII.

The Encyclical was primarily aimed at legitimizing the right of private ownership, specifically property, against claims by "Socialists.” Socialists:

...by endeavoring to transfer the possessions of individuals to the community at large, strike at the interests of every wage earner, since they would deprive him of the liberty of disposing of his wages, and thereby of all hope and possibility of increasing his resources and of bettering his condition in life (Leo XIII, 1891, Para. 5).

Having established that "private ownership is in accordance with the law of nature" (Leo XIII, 1891, Para. 9), Leo XIII asserted that the human obligation to "maintain the balance of the body politic” rendered it a “...great mistake...to take up with the notion that class is naturally hostile to class, and that the wealthy and the working men are intended by nature to live in mutual conflict” (Leo XIII, 1891, Para. 19). The employer should, according to Leo XIII (1891, Para. 20), "give everyone what is just.” Leo offered an important description of the nature of human labor. He wrote:

\footnotetext{
${ }^{5}$ In e-mail correspondence, David Kettler (June 2008) noted the Catholic parties took up defensive "traditional" positions against the emerging Weimar norms on works councils. Yet, even these struggles took place in a wider context of mutual Christian knowledge. Kettler is the co-author of Kettler and Tackney (1995) and an expert in Weimar labor law history.
} 
Hence, a man's labor necessarily bears two notes or characters. First of all, it is personal, inasmuch as the force which acts is bound up with the personality and is the exclusive property of him who acts, and, further, was given to him for his advantage. Secondly, man's labor is necessary; for without the result of labor a man cannot live, and selfpreservation is a law of nature, which it is wrong to disobey (Leo XIII, 1891, Para. 44).

He concluded this point by stating, “...these two aspects of his work are separable in thought, but not in reality” (Leo XIII, 1891, Para. 44).

A few other points in this Encyclical are noteworthy: the prevention and correction of strife that appears grounded in class conflict remains the purview of "Christian institutions," such as the Church (Leo XIII, 1891, Para. 19). In addition, the Pope noted that there can be no doubt, “civil society was renovated in every part by Christian institutions” (Par. 27). These, in turn, have an obligation to alleviate conditions of the masses that are inappropriate or exploitative. The interests of the "working man" should be protected by the State (Par. 40). To this end, public measures are appropriate to overcome issues, such as strikes, which may arise due to excessive working hours or inappropriate conditions (Par. 39). Associations of employers and workers, separate or together, can be aids that draw the classes together; "The most important of all are workingmen’s unions” (Par. 49).

Two aspects of law drew the particular attention of Leo XIII. He wrote, "The law, therefore, should favor ownership, and its policy should be to induce as many as possible of the people to become owners” (Par. 46). Furthermore, in light of danger to the public peace occasioned by labor disputes, he wrote, “The laws should forestall and prevent such troubles from arising; they should lend their influence and authority to the removal in good time of the causes which lead to conflicts between employers and employed” (Par. 39). 
The exact degree of influence of the Encyclical Rerum Novarum upon the efforts of the CLRC's 1946 Guidelines is difficult to estimate and beyond the intent of the present research effort. We know, however, from Suehiro's texts, that he had thorough knowledge of the Encyclical (Suehiro, 1988). Prima facie, the textual consonance in viewpoint and tone is striking and unmistakable. The CLRC ends its recommendation on management councils by stating:

Accordingly, harmonious solutions to these issues are expected. It is unreasonable to wait for legally binding resolutions: appropriate provisions ought to be previously included in the firm's articles of incorporation. Without exception, legal issues inherently contain paths to a resolution. (See Appendix 1)

By situating the German works council organizational form within the provisions of firmspecific collective bargaining agreements, Japan’s 1946 CLRC, in one legal stroke, institutionalized a process that eventually overcame the plant takeover disputes of the period. This achieved the point of law envisioned by Leo XIII cited earlier:

The laws should forestall and prevent such troubles from arising; they should lend their influence and authority to the removal in good time of the causes which lead to conflicts between employers and employed.

\section{0: Personal Intellectual Conversion? An Asian Moment of Cosmopolis?}

Under the Allied Occupation, labor legislation reflecting the New Deal labor laws of the United States were passed through the Japanese Diet (the legislative body). The Trade Union Law provided for the creation of a remedy institution to deal with industrial disputes in the form of a CLRC, with its regional Commissions. The CLRC and its regional affiliates are modelled upon the US National Labor Relations Board that was part of New Deal labor legislation enactments. Nine members compose the CLRC. They are appointed by the Ministry of Labor. 
They represent employers, employees and the public interest. The CLRC public interest representative, by law, must be approved by those representing employer and employee interests.

The first public sector representative was Suehiro Izutaro, former Professor of Law and Dean of the Imperial University Law School. This was the position he migrated to following, and despite, his 1946 purge from the School in the immediate aftermath of the Occupation. His purge was due to his role as the coach of a martial arts club. This was later deemed to be an excessive act and his purged status was formally rescinded.

Professor Suehiro was one of many Japanese legal scholars who pursued advanced studies overseas. He completed law studies at the German Law Department of the Tokyo Imperial University in 1912. Following a short teaching period, he went abroad for further studies: first to the University of Chicago, then on to Europe where he was drafted into the Japanese delegation for labor issues at the Treaty of Paris, in Versailles, which formally ended World War I.

It was at the University of Chicago Law School that Suehiro underwent some form of profound inner conversion: certainly it was an intellectual conversion, as a committed legal scholar, it may have been considerably more. ${ }^{6}$ As a graduate student overseas, and unfamiliar with English, he nevertheless decided to attend a class in case law. Watching the students being aggressively queried by the professor about the cases and their underlying legal issues, he reported that he realized, in that classroom experience, that everything he had studied and learned about law in Japan was meaningless. The ‘top-down’ application of legal abstractions to concrete instances missed the facts of life being driven home to the students by that American professor. He left that class a different law student.

\footnotetext{
${ }^{6}$ In a culture such as Japan where individuals do not generally 'think about' transcendent concepts of divinity in the way of the West, assessments of religious conversion may be somewhat of a challenge.
} 
He went on to Europe. Suehiro studied for a time under Eugen Ehrlich, who is the father of the sociology of law. After aiding the Versailles Peace conference, he returned to Japan.

Once back, Professor Suehiro soon established the first case law research group in order to use social scientific principles in the study of legal norms as they are evidenced in specific judicial decisions. His approach was empirically grounded, seeking, inductively, to derive principles of "living law" from collections of cases. ${ }^{7}$ He took up teaching and research at the Law School of what is now Tokyo University. He was, as noted, Dean of the Law School by the end of World War II. Thus, in practice, he was formally responsible for the academic training of an entire generation of Japanese legal scholars. He was, in addition, the leading labor law scholar in the country. ${ }^{8}$

The next significant development in postwar Japanese industrial relations was also largely due to the influence of Suehiro Izutaro. As mentioned, he was the first public sector representative on the first CLRC, assuming the role of CLRC chair after the first chairman resigned. Faced with a series of plant takeovers by workers, the CLRC, at the request of the Ministry of Labor, issued a set of guidelines on July 17, 1946, titled, “Central Labor Relations Commission Guidelines for Management Participation Forums.” Thereafter, the intransigent relations between management and labor changed. What followed was a quest for national recovery and sustainable operations in the manufacturing sector.

\footnotetext{
${ }^{7}$ It is interesting to note that Japanese law does not follow the stare decisis (precedent) norm-setting characteristic of U.S. law. Each justice has two obligations that bear on any case: her or his conscience and the Japanese Constitution. Patterns of similar decisions obtain a sort of "crystallized custom" normative standard. Lifetime employment is one example.

${ }^{8}$ On Suehiro Izutaro’s career, see Chuo Rodo Jiho (CLRC Times),(1951) in Japanese. In English, the most detailed account of his life, to my knowledge, is Ketter, D., and Tackney, C.T. (1997). His continued employment during the war in such a prestigious position, along with actual social science studies he led in Occupied Manchuria, left a complex legacy. His treatment in Japan recalls the circumstances of Martin Heidigger, whose postwar career was shadowed by initial support for the National Socialist Party.
} 
Suehiro was not without uncertainty in the norms he helped devise. It was not clear to him, for example, that workers would be up to the studious task of learning the issues required to participate in discussions of managerial prerogative. Furthermore, he felt some uncertainty that the enterprise union form that emerged in Japan would be an authentic and properly independent labor union structure. He wrote, at one point, that it would take a decade or more to know if their decisions were appropriate.

Suehiro devoted the last years of his life to professional involvement in every major, and many more minor, labor disputes. His granddaughter recalled him leaving after dinner, driven away by a car with a driver, and returning only early in the morning. He was noted for beginning mediation with a favorite phrase, “Ok, so what are the facts?”(じゃあ、、、事実はなんです か。 ). He coupled a strong grounding in social science - empiricism - with a firm belief that conflict inherently contained the seeds of its own resolution - this is, in terms of a functioning and professional legally grounded epistemology that was thrust into the worst possible disputes of industrial society, a remarkable - arguably breathtaking - balancing act.

As the public sector representative to the CLRC, he preserved a careful non-partisan stance at a time when Communists were seeking proletarian revolution in the factory and workers were actively engaged in "production control" assumption of the means of production locking out the owner who had refused to negotiate over wages and working conditions.The Japanese managers, then, were little better. They had no prior experience of a negotiated managerial prerogative. He mediated between Party members and plant owners. He was known to keep a small metal flask of whiskey in one pocket for the long negotiation sessions.

Shortly before his death, he was part of a tour group of Japanese dispatched by the Supreme Command Allied Powers (SCAP) to the United States so that the defeated enemy could 
learn about democracy. Apparently he said some things about worker rights that upset the local American press. The State department quietly recommended to SCAP that Suehiro be repatriated early on the pretense of a needed meeting. SCAP refused; he was not saying anything back in America he had not already said in newly democratized Japan.

Suehiro passed away in 1954, some years before Japan’s postwar “economic miracle” began to be noticed, either domestically or overseas. In the subsequent decades, Japan's “web of rules” underwent ongoing specification of employment relations through collective bargaining agreements, the famous "Spring Offensive" (coordinated wage and working condition improvement calls by organized labor), the mediation of disputes through the CLRC and its regional affiliates, and case law decisions that established evolving norms for appropriate behavior on the part of management and labor, given the employment ecology parameters previously specified.

Despite the decades long media reports and researcher claims that lifetime employment in Japan is inefficient, outdated, or non-existent, this institutionalized practice continues to be regulated by Japan's courts and case law. The simple fact is that the Western media and most researchers do not read Japanese case law, so they do not know. The most recent labor legislation reforms show no evidence of a shift to American style at-will employment. To the contrary, workers who are dismissed now have the right to receive a prompt and clear statement of the grounds for dismissal. Such documents can be brought to courts in Japan and a "provisional disposition” sought - the same day. Provisional dispositions are measures invented by Japanese judges to provide immediate remediation to the discharged worker, until the court case is formally resolved (a process notoriously slow - perhaps a decade). If the judge finds in favor of the dismissed, which they do with remarkable frequency, then the "provisional disposition" 
effectively revokes the dismissal until formal determination. The dismissed is entitled to job access and compensation until the case is formally resolved. Needless to say, Japanese managers are extremely careful in the matter of employee dismissals.

\section{Discussion}

If we reflect on the considerable historical ground we have covered in this paper, and reflect on this from the perspective of Lonergan studies, perhaps the first and most troubling question to ask could be stated as, "What if the global collaboration that we seek, anticipating cosmopolis, actually began over half a century ago in Japan, but no one over here ever noticed?”

This is not an easy question to take up - it has any number of implications. When the author, as a Jesuit scholastic, was preparing to be sent to Japan for Regency in 1980, one spiritual advisor strongly cautioned against any missionary optimism; “If you're going with an expectation of baptizing Japanese, well, I hear that doesn't happen very often.” The author was not told that Japan had self-evangelized the worksites of the entire nation according to principles of industrial democracy that easily matched Roman Catholic social teaching - and was busily exporting it around the world under the guise of Japanese management practice. Nor was he told that these employment norms were more in keeping with Roman Catholic social teachings than had yet to obtain then - or even to this day - in the nation he was leaving for 'missionary' work.

There are a number of other topics of possible interest I will note sequentially, which strike me as being worthy of more work, and will benefit from advice from those more familiar with Lonergan. These points will move from industrial relations into other (for me exotic) aspects of the greater Lonergan research community. Given time and, of course, appropriate insight, I will add more at the Workshop presentation itself. 
a. Basic (productive) and higher order (finance) cycles require appropriate checks to ensure adequate distribution of gain and minimize disruptive variance between boom and bust. I have yet to find words on how Lonergan thought about this. From an industrial relations perspective, works councils, or their clever Japanese variant, ensure against excessive CEO compensation. The problem Americans face in this regard is wholly their own.

b. Postwar Japan did well with management councils in the productive sector. They were less successful with their deployment in their own financial sector. Thus, the 1990s were a lost decade due to inappropriate management of wealth.

c. The proposal to localize works councils in collective bargaining units is not a panacea. Japanese courts and jails have their share of executives and labor leaders who have broken the law. Badly deployed in any circumstance, Japanese management production line regime pressures can exceed Taylorism in exploitation, in that they also demand the workers’ entire consciousness, not just repetitive physical motions.

d. Nevertheless, it appears that the American future for a manufacturing sector that is productive, sustainable, and globally competitive must adopt this “choice of just one thing,” invent a functional equivalent, or fail.

e. if we acknowledge Lonergan's insight into the need for a new approach to political economy, and couple that with his obvious - if carefully nuanced - faith in the future of humanity as evidenced in the construct of 'cosmopolis,' then where shall we go to seek signs of its emergence? Is the Japan case one example? Might it be an exemplary case? Are we not obliged to verify philosophical economics in the concrete facts of history - in precisely the measure of which Lonergan spoke: "a democratic economics that can issue practical imperatives to plain men”?(NPE, p. 7) 
Finally, we end by noting that today, some 63 years after the CLRC issued its recommendation, Suehiro's uncertainty over what he sought to achieve in Japan is now transformed to whether or not the United States industrial relations system is able and, significantly, willing to learn from his simple, clear, and appropriate insight in crafting a few practical imperatives for plain men and women.

Discussion and debate over this simple proposal should occur. It began, I am happy to note, at the Lonergan Workshop, in the discussion following the paper’s presentation. One audience member claimed that this proposal was 'ideological' in nature. In fact, it is ideological only to the extent it is grounded in empirical method; the only way to effectively determine the comparative utility of the Japanese approach in the U.S. system is to permit experimentation. It is precisely the refusal to permit experimentation that will manifest 'ideological' convictions. 


\section{References}

Adler (2001). Market, Hierarchy, and Trust: the Knowledge Economy and the Future of Capitalism. Organization Science. 12:2. Pp. 215-234.

Aoki, M. (1987). The Japanese Firm in Transition. In K. Yamaura and Y. Yasukichi (Eds.). The Political Economy of Japan: Volume 1, The Domestic Transformation (pp. 263-288). Stanford: Stanford University Press.

Aoki, M. (1988). Information, Incentives, and Bargaining in the Japanese Economy. Cambridge: Cambridge University Press.

Dunlop Commission (1994). The Dunlop Commission on the Future of Worker-Management Relations Final Report. Readily available on the Internet from various sources. For example http://digitalcommons.ilr.cornell.edu/key workplace/2/

Dunlop, J.T. (1958 and 1993). Industrial Relations Systems (and Revised Edition). New York: Holt, Boston: Harvard Business School Press.

ETUC. Co-determination is not an alien concept in Europe. http://www.etuc.org/a/382.

Fukuyama, (1995). Trust. London: Free Press.

Jackson, G. (2001). The Origins of Nonliberal Corporate Governance in Germany and Japan. In W. Streeck and K. Yamamura (Eds.). The Origins of Nonliberal Capitalism: Germany and Japan in Comparison. Pp. 121-170. Ithaca: Cornell University Press.

Kaufman, B. (2004), “The roots of industrial relations”, The Global Evolution of Industrial Relations, International Labor Organization, Geneva.

Kettler, D., and Tackney, C.T. (1997). Light from a Dead Sun: the Japanese Lifetime Employment System and Weimar Labor Law. Comparative Labor Law and Policy. 19(1). 1-41.

Kochan, T.A., Katz, H.C., and McKersie, R.B. (1984). Strategic Choice and Industrial Relations Theory. Industrial Relations. 23:1. Pp. 16-39.

Kochan, T.A., Katz, H.C., and McKersie, R.B. (1986). The Transformation of American Industrial Relations. New York: Basic Books.

Koike, K. (1988). Understanding Industrial Relations in Modern Japan. London: Macmillan.

Leo XIII (1891) Rerum Novarum (Encyclical of Pope Leo XIII on Capital and Labor), available at: www.vatican.va/holy father/leo xiii/encyclicals/documents/hf l-xiii enc 15051891 rerum$\underline{\text { novarum_en.html }}$

LexDB 270008595 (1968), This is a proprietary case law database, all texts are in Japanese. The cited Supreme Court case of December 25, 1968 (Showa 43) is also given in Hanrei Jiho, 
No. 512, p. 9, available at: www.tkclex.ne.jp/

LexDB 27611297 (1961), The Osaka Regional Court case of July 19, 1961 (Showa 36) is also given in Hanrei Jiho, No. 270, p. 11, available at: www.tkclex.ne.jp/

LexDB 28020596 (1997), The Japanese Supreme Court decision of February 28, 1997 (Heisei 9) is also given in Hanrei Jiho No. 1597, p. 7, available at: www.tkclex.ne.jp/

Liker, J.K., Fruin, W.M., \& Adler, P.S. (1999). Remade in America: Transplanting and Transforming Japanese Management Systems. Oxford: Oxford University Press.

Lonergan, B. J. F. (1992). Insight: A Study of Human Understanding. The Collected Works of Bernard Lonergan, Vol. 3., The Robert Mollot Collection. Toronto: University of Toronto Press.

Morgan, J.M., \& Liker, J.K., (2006). The Toyota Production Development System. New York: the Productivity Press.

Rogers, J. and Streeck, W. (1995). Works Councils: Consultation, Representations, and Cooperation in Industrial Relations. New York: the University of Chicago Press.

Streeck, W. (1995). Works Councils in Western Europe: from Consultation to Participation. Works Councils: Consultation, Representation, and Cooperation in Industrial Relations. Pp. 313-348. New York: The University of Chicago Press.

Suehiro, I. (1988) in Kawashima, T. (Ed.), Uso no Koyo (The Utility of Lies),Toyamabo, Tokyo.

Tackney, C.T. (1995). Institutionalization of the Lifetime Employment System: a Case Study of Changing Employment Practices in a Japanese Factory. Madison: University of Wisconsin-Madison.

Tojo, M. (1949). The Character of Management Consultation Forums (Keiei kyogikai no seikaku), in I. Suehiro (Ed.), Toward an Industrial Society and Management Participation of Labor Unions (Sankyo shakakai to rodo kumiai no keiei sanka). Tokyo: Takayama Shoin. Pp. 177-202. 
Figure 1: The Legal Employment Ecology of the U.S. Enterprise

\author{
American Management
}

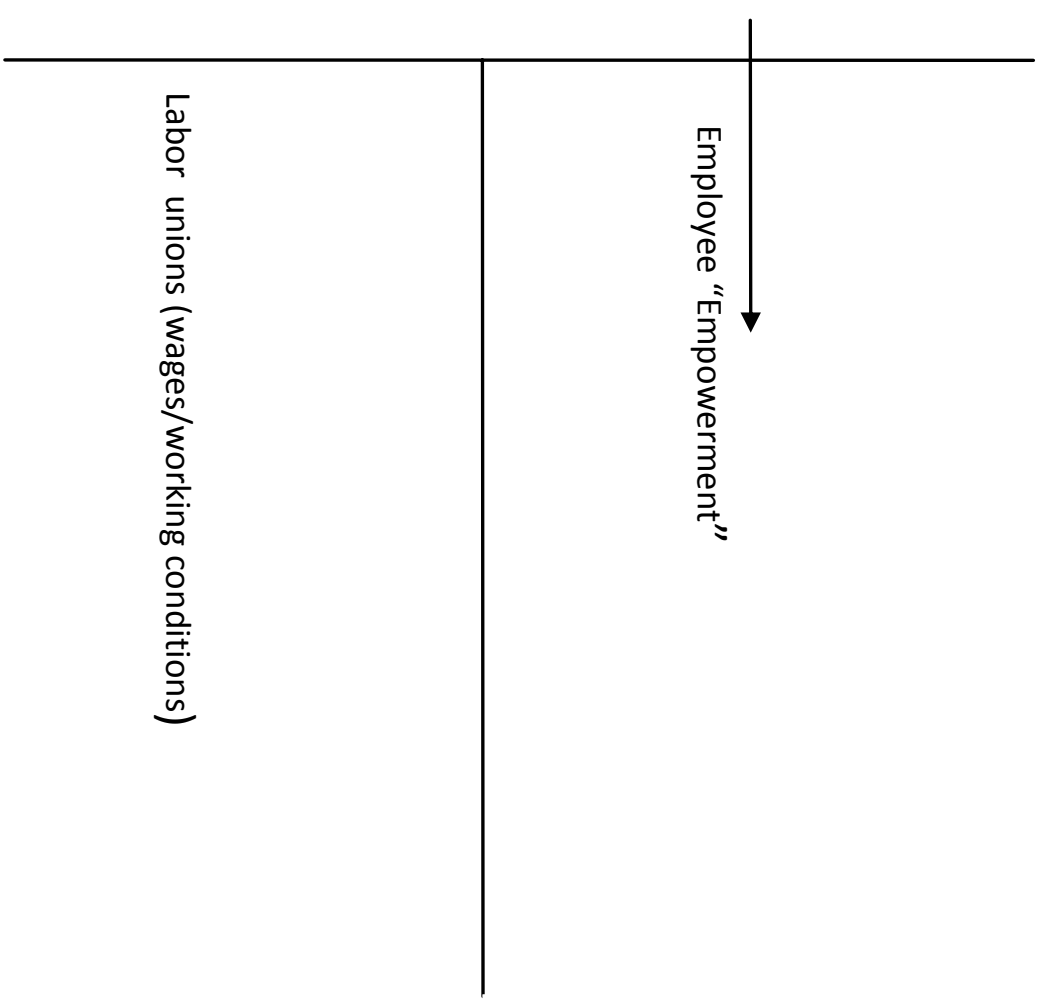

Good, bad, or no reason: "at will", with federal, state and union

Dismissal / restrictions.

participation:

No (not since the New Deal) 
Figure 2: The Legal Employment Ecology of the German Enterprise

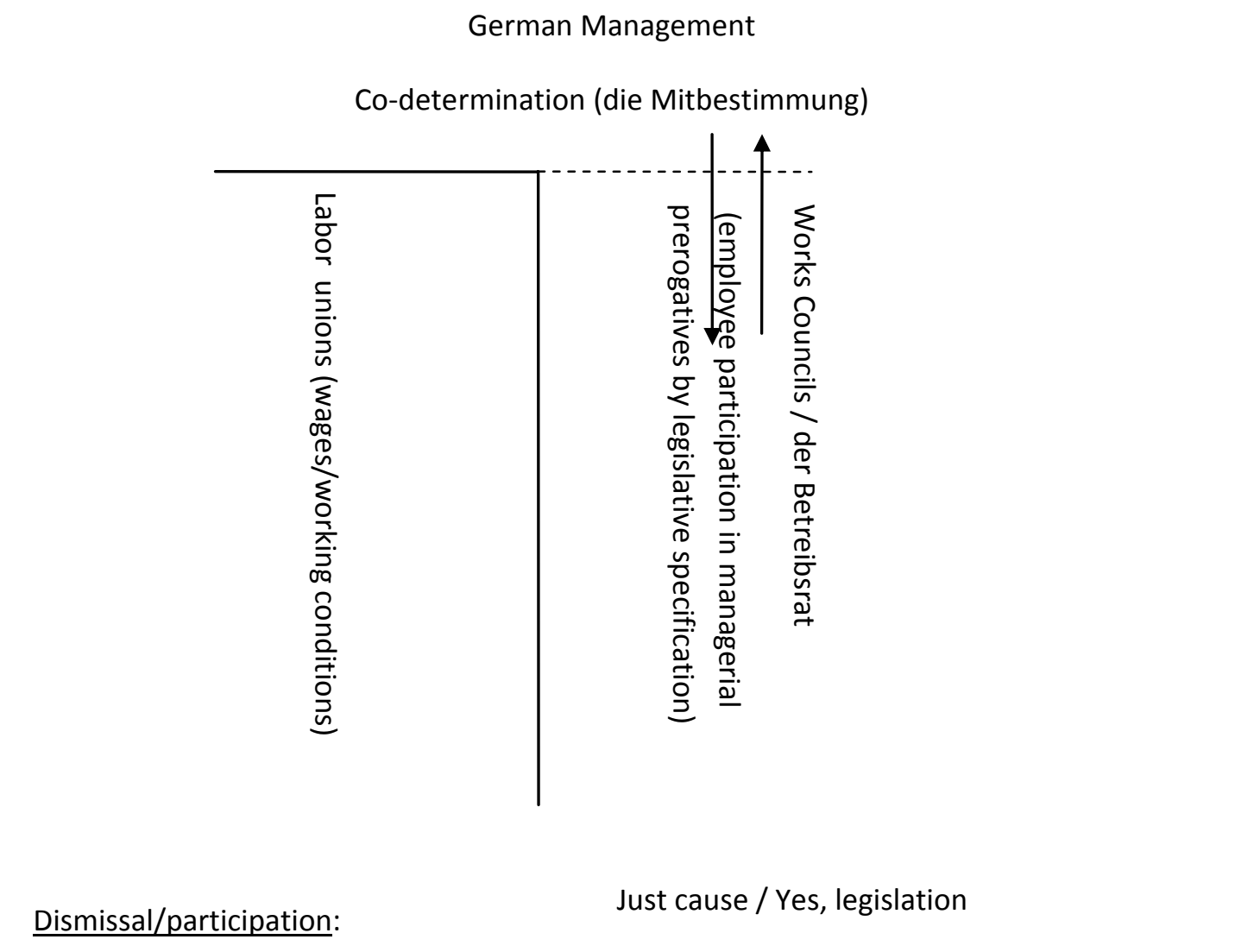


Figure 3: The Legal Employment Ecology of the Japanese Enterprise

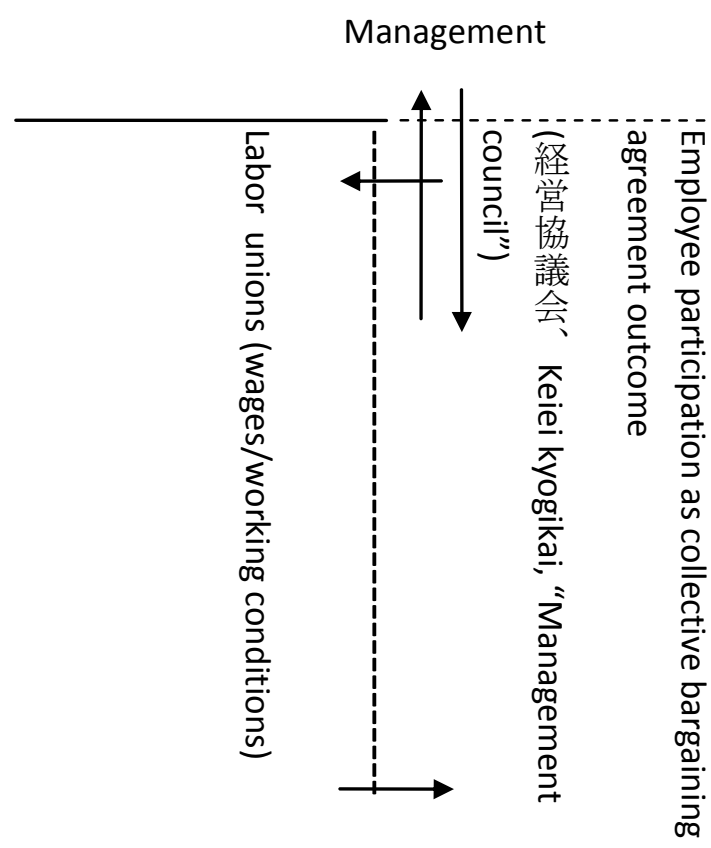

Dismissal/participation:

Just cause / collective bargaining outcomes:

"Management Councils" 


\section{Appendix 1: Central Labor Relations Commission Guidelines for Management Participation Forums}

(Issued, July 17, 1946)

(Tojo, 1949. Original in Japanese, this author's translation.)

The establishment of management participation forums is recommended by determining suitable terms in collectively bargained agreements according to the specific characteristics of each enterprise. This is because conformity to a forcibly determined set of one-sided regulations can easily give rise to structures uselessly created which do not adequately demonstrate the original function of such forums. Moreover, if we consider the various bargaining disputes, given the actual circumstances of management participation forums now being established and the different aspects of management participation forum establishment, there are points that specifically need to be considered in establishing management participation forums now. Providing reference material to facilitate reflection on these problems for those generally involved to enable logical commentary will help avoid one-sided, useless argumentation. At the same time, no small contribution will be made by adequately demonstrating the essential function of management participation forums.

This guide is based upon the present condition of management participation forums along with that of current collective labor contracts. It is also aimed at qualitative improvement in the practical utility of future collective agreements and the gradual development of the range of items that should be dealt with through the function of management participation forums. The following commentary is based upon the standard of the ordinary publicly held (stock) firm. However, adequate attention is also given the respective features of non-private, managed enterprises, such as the national railways, as there is a rough resemblance in principles. 


\section{The essence of management participation forums}

Management participation forums are based on the spirit of industrial democracy. As workers actively participate in the management of labor, it is a permanent participation forum established through collective bargaining between the labor union and the employer. Different from a simple roundtable conference or an inquiry session, representatives of the employer and labor union meet as equal forum members. Both sides assume the duty of planning for implementation of items that are decision outcomes. However, in establishing management participation forums, there is no change in official duty and competence of enterprise executive for general direction of overall management. Simply that what was hitherto despotically decided and implemented by the executive will instead become the assumption of a duty to implement decisions specifically made by the management participation forums.

Moreover, for publicly held corporations stock may be given to workers so they may attend the general shareholders meeting. An individual recommended by the labor union may become a member of the board of directors. These and other methods of worker participation are conceivable, but they are completely different from management participation forums. Management participation forums premise to the utmost that the management executive and labor union stand together; these forums are institutions that recognize continuing management participation by the worker.

\section{The establishment of management participation forums}

Management participation forums are established through collective agreements between employers and labor unions. Accordingly, if an employer one-sidedly established a mechanism to permit worker participation in management without relying on a collective agreement, this mechanism would not be a management participation forum.

\section{The constitution of management participation forums}


Management participation forums are constituted by representatives of management and workers as defined by a collective agreement.

a. The number of members may be determined by option through the collective agreement. It is not necessary that the employer and labor sides always have the same number. When faced with a difficult problem, a one to one opposition will in the end develop. For multiple problems decisions will not be able to be made as stated in the postscript.

b. The executive officials are free in terms of how many will be put forth to represent the employer. However, to further progress in harmony in the forum, it is desirable that the president, managing director and plant chief attend of their own responsibility. Otherwise, after something has been decided in the management forum, the board may reject it. This would, in turn, easily give rise to friction with the labor union.

c. Forum representatives of labor are to be decided according to independent, formal procedures. Interference in their selection by the employer will not be permitted. The representative(s) of the labor side should have the confidence of the entire labor union. These individuals should necessarily have complete representative competence. If possible, those things that the representatives obtained unanimity about should be, in the same way, followed by the labor union so that all labor union members are so constrained

d. Adding a third party representative is to be determined as an option of the collective agreement. For example, for public transportation enterprise functions which directly relate to daily life of the public, there are many good occasions where it would be good to include a third party public representative.

\section{The authority of management participation forums}


The authority of the management participation forum, that is, the degree to which workers are permitted to participate in management, is something suitably specified in collective bargaining according to the characteristics of each enterprise. The nature of the firm and the actual power of the labor union involved logically provide one self-certain range of limit. Current law provides no legal enforcement to that specified limit. If we consider actual examples:

a. Issues for participation are, most ordinarily, working hours, wages and the manner of wage payment according to legal standards. In addition, other issues may involve those related to appropriate working conditions, labor welfare, improvement of labor productivity, regulation of the intensity of work, and other issues related to the preservation of labor power. Principally, items for discussion also concern those related to the profit of the actual workers, such as practices of worker health and welfare, issues dealing with materials distribution, productivity measurement documents and necessary work documents for such activities. There is no legal understanding extant regarding the limitations of management participation forums in respect of their authority arising from their nature.

b. Personnel standards related to worker hiring, dismissal and other matters, such as work organization, are not infrequently considered to be management participation issues concretely involving participation in actual personnel matters. However, actual participation in personnel matters may, conversely, easily give rise to a variety of negative effects. Thus, to instead obtain labor union understanding, a degree of room for objection would seem good to allow and define in advance within the collective agreement.

c. It is not a legal violation of forum structure to include issues like profit distributions, directors and other company executive personnel matters in management participation forums. However, to prevent problems from arising in regard to the firm's articles of incorporation, these rules should be 
included therein. Otherwise there is a danger that a problem may arise afterward in regard to invalid restraint of the general shareholders' meeting under the law.

d. In the event of a dispute, this should necessarily be discussed within the management participation forum and a solution found. Otherwise, it is desirable to have preventive means in place through clause articles that insure disputes between both sides do not occur.

In addition to the preceding points, other items for participation forums include detailed manifestation of accounting details of the firm, this in order to obtain worker understanding. This will have no small role in preventing disputes and sustaining labor relations harmony.

\section{The character of management participation forums}

A management participation forum is not a simply round-table meeting [懇談会, kondankai]. Opinions about participation forum issues should be stated without alienation by both labor and employer sides to facilitate understanding. This is the mission of these forums. Accordingly,

a. Forum resolutions should, by custom, be reached in unanimity. Even if resolution methods are set by agreement that involve rules applied to complex decisions, these are not usually of practical effect. If the opinion of participants on both sides divides over a major issue, it will not matter how many the number of participants are, the result will be a one-to-one opposition and participation forum solutions will naturally not obtain.

b. Accordingly, for such instances of opposition, it will be good to have established clauses in advance for third party mediation, arbitration or final arbitration.

c. The effective force of forum resolutions should be understood as being identical to the effect of collective agreements. Participants share a common obligation to work for the actualization of such 
resolutions. In the event a certain resolution requires shareholder action or approval, there should be no procrastination. In the absence of shareholder action, the firm will only be all the more legally constrained. In practice, the effort of those representing the firm in the management participation forum can generate acceptable proposals based on reflection over actual company circumstances. Accordingly, harmonious solutions to these issues are expected. It is unreasonable to wait for legally binding resolutions: appropriate provisions ought to be previously included in the firm's articles of incorporation. Without exception, legal issues inherently contain paths to a resolution. 